\title{
Peran Permainan Ludo Dalam Mengembangkan Kemampuan Kognitif Anak Usia 5-6 Tahun
}

\author{
Rosita Wondal $^{1}$, Rita Samad ${ }^{2}$ Desna Kore $^{3}$ \\ Universitas Khairun Ternate \\ Fakultas Keguruan dan Ilmu Pendidikan \\ Jl. Bandara Sultan Baabullah Kota Ternate Utara, Kotak Pos 53 Ternate 977328 \\ Telepon: (0921) 3110905-Faksimili 0921-3110901 \\ Email: rositawondal80@gmail.com
}

\begin{abstract}
Abstrak: Bermain merupakan cara anak dalam belajar. Dengan bermain anak akan mendapatkan sejumlah pengalaman-pengalaman serta tantangan baru yang akan memperkaya diri anak baik dari segi pengenalan nilai-nilai agama dan moral, fisik motorik, bahasa, kognitif, sosial emosional bahkan seni anak akan berkembang ketika anak melakukan kegiatan bermain. Pendekatan yang tepat dalam mengajar pada anak usia dini adalah dengan kegiatan bermain. Salah satu permainan yang disenangi anak masa kini adalah permainan ludo. Permainan ini dapat diciptakan sendiri oleh guru dengan bahanbahan bekas yang ada di lingkungan sekitar. Berdasarkan penelitian kajian literatur dapat disimpulkan bahwa permainan ludo dapat membantu perkembangan kognitif, khususnya anak dapat mengenal konsep angka sederhana (1 sampai dengan 6) dengan dadu yang dimainkan, anak juga dapat mengetahui konsep banyak-sedikit dan panjang-pendek
\end{abstract}

Kata kunci: Permainan Ludo, Kemampuan Kognitif

Abstract: Play is a way for children to learn. Children will get experiences and new challenges that will enrich their religious and moral values, physical motor and language, cognitive, social emotional, even art development when they do play activities. One of the approaches in teaching early childhood is game. A game is activity which executed only for pleasure and sometimes used as an educational tools. Ludo is one of them. This game can be created by the teacher himself using used materials around us. Based on the literature review, it can be concluded that ludo game can improve cognitive development, especially children can recognize the concept of simple numbers ( 1 to 6) with the dice being played and they also know the concepts of many-little and long-short.

\section{Keywords: Ludo Game, Cognitive Ability}

\section{A. Pendahuluan}

Masa kanak-kanak merupakan suatu periode pada saat individu mengalami perkembangan yang sangat pesat. Banyak ahli menyebut periode ini sebagai golden age (masa emas) dalam kehidupan seseorang. Anak Usia dini merupakan anak dalam rentang usia lahir sampai dengan 6 tahun. Pendidikan anak usia dini (PAUD) merupakan suatu lembaga pendidikan yang melayani anak usia dini dengan memberikan stimulus ransangan pendidikan guna anak siap untuk memasuki jenjang pendidikan selanjutnya. Rangsangan pendidikan yang diberikan bagi anak tentu saja haruslah sesuai dengan usia serta karakteristik perkembangan anak. PAUD 
merupakan satu tahap pendidikan yang tidak dapat diabaikan karena ikut menentukan perkembangan dan keberhasilan anak. Seiring dengan perkembangan pemikiran tersebut, tuntutan dan kebutuhan layanan pendidikan anak usia dini pada saat ini cenderung semakin meningkat.

Anak merupakan seorang individu yang mengalami proses pertumbuhan dan perkembangan yang sangat pesat. Vigotsky dalam Khadijah (2016), mengatakan bahwa perkembangan anak tidak lepas dari lingkungan dan budaya yang membentuknya Anak memiliki kemampuannya sendiri yang disebut Child's actual developmental level (level 1) Yaitu kemampuan problem-solving anak yang bekerja tanpa bimbingan orang dewasa Potential development under optimum circumstances learning with a competentnurturing mediator.(MLE - Mediated Learning Experience) (level 2) Yaitu kemampuan anak setelah adanya "directed learning" dibawah bimbingan orang dewasa (mediasi yang menginterpresi lingkungan).

Salah satu aspek yang dikembangkan sejak dini adalah kemampuan kognitif anak. Suyanto (2005) berpendapat bahwa perkembangan kemampuan kognitif anak usia dini merupakan proses kemampuan berfikir dalam mengenal konsep berhitung yang berhubungan dengan penjumlahan dan pengurangan serta mengenal angka sesuai dengan tahap perkembangan anak. Pendekatan perkembangan kognitif menekankan bagaimana anak secara aktif membangun cara berpikir mereka dari satu titik perkembangan ke perkembangan selanjutnya.

Untuk mengembangkan kemampuan kognitif anak guru dapat menggunakan permainan dalam proses pembelajaran. Bermain adalah kesempatan bagi anak untuk bereksplorasi, mengadakan penelitian-penelitian, mengadakan percobaan percobaan, untuk memperoleh pengetahuan. Pada anak usia dini, bermain merupakan karakter anak. Bermain merupakan wahana anak dalam memperoleh segala informasi yang akan ditangkap anak melalui panca indranya. Dengan bermain anak akan mendapatkan sejumlah pengalaman-pengalaman serta tantangan baru yang akan memperkaya diri anak baik dari segi pengenalan nilai-nilai agama dan moral, fisik motorik, bahasa, kognitif, sosial emosional bahkan seni anak akan berkembang ketika anak melakukan kegiatan bermain. Bermain memberikan kesempatan kepada anak untuk berinteraksi dengan objek. Anak memiliki kesempatan menggunakan inderanya, seperti menyentuh, mencium, melihat, dan mendengarkan untuk mengetahui sifatsifat objek tersebut. Dari pengindraan tersebut anak memperoleh fakta-fakta, informasi, dan pengalaman yang menjadi dasar untuk berfikir abstrak. Tahapan perkembangan kognitif anak PAUD B berada pada tahap praoperasional. Tahap tersebut segala aktivitas kognisinya belum mampu pada hal-hal yang abstrak, sehingga perlu kegiatan yang bermakna dan kongkrit dalam menciptakan pengalaman baru yang menjadi sumber pengetahuan baginya. Jadi bermain menjembatani anak dari berfikir kongkrit ke berfikir abstrak.

Salah satu cara efektif belajar pada anak usia dini adalah melalui bentuk permainan (Hapsar, 2015). Bermain merupakan proses pemecahan masalah. Pada saaat bermain anak dihadapkan pada berbagai situasi, kondisi, teman dan objek baik nyata maupun imajiner yang memugkinkannya menggunakan berbagai kemampuan berpikir dan memecahkan masalah (Suyanto, 2005). Melalui kegiatan bermain, perkembangan kognitif anak dapat semakin berkembang. Dalam permainan ludo perkembangan kognitif yang dapat berkembang adalah kemampuan berhitung permulaan anak. Anak mulai mengenal konsep angka sederhana dengan dadu yang 
dimainkan anak serta anak dapat mengetahui konsep banyak-sedikit dan panjangpendek.

Penelitian tindakan kelas yang dilakukan oleh Jawati (2013) dengan subjek penelitian anak PAUD Habibul Ummi II. Pada kelompok usia 5-6 tahun yang berjumlah 12 orang pada semester I tahun ajaran 2012-2013. Penelitian ini dilakukan dalam dua siklus yaitu masing-masing siklus 3 kali pertemuan. Teknik pengumpulan data menggunakan observasi menyimpulkan bahwa melalui permainan ludo geometri dapat meningkatkan kemampuan kognitif anak usia dini 5-6 tahun dalam aspek mengenal bentuk geometri, mengenal bilangan, dan mengelompokkan warna. Terlihat peningkatan kemampuan kognitif anak dalam mengenal bentuk geometri (lingkaran, segitiga, dan segiempat), terlihat adanya peningkatan kemampuan kognitif anak dalam aspek mengenal bilangan (1 sampai 20), dan terdapat peningkatan kemampuan kognitif anak dalam aspek mengelompokkan warna (merah, kuning, hijau, dan biru) dengan menggunakan permainan ludo geometri.

Penelitian dari Afrianti dkk (2018) melakukan penelitian tindakan kelas menemukan hasil penelitian menunjukan bahwa hasil belajar peserta didik melalui permainan tradisional ludo, sebelum dilakukan penelitian dengan persentase $31,9 \%$, siklus I mengalami peningkatan dengan persentase 58,7\%, dan pada siklus II mengalami peningkatan lagi dengan persentase $77,1 \%$. Berdasarkan hasil penelitian, maka dapat disimpulkan bahwa melalui permainan tradisional Ludo dapat meningkatkan kemampuan kognitif anak usia dini 5-6 tahun dalam aspek mengenal bentuk geometri, mengenal bilangan, dan mengelompokkan warna.

Permainan Ludo sudah pernah dimainkan anak-anak sekarang baik dalam game konvensional maupun game online. Permainan merupakan kegiatan yang sangat menyenangkan bagi anak. Orang dewasa cenderung menilai bermain bagi anak hanyalah membuang waktu belaka. Namun bermain bagi anak merupakan ajang belajarnya. Dalam permainan terdapat sejumlah paraturan-peraturan yang wajib dipatuhi anak. Dalam suatu permainan terkandung nilai-nilai yang diperolah anak seperti: jiwa pantang menyerah, sabar menunggu giliran, siap menerima kekalahan dan lain sebainya. Hasil penelitian dari Jawati menyatakan bahwa melalui permainan ludo geometri dapat meningkatkan kemampuan kognitif anak usia dini 5-6 tahun dalam aspek mengenal bentuk geometri, mengenal bilangan, dan mengelompokkan warna (Jawati, 2013).

Permainan ludo merupakan salah satu permainan yang mulai dikenal anak serta cukup menarik bagi anak. Permainan ludo semakin berkembang di era teknologi digital. Versi digital dari permainan ini dikembangkan dalam bentuk aplikasi. Jenis permainan Ludo berbentuk board game kini banyak dijumpai di smartphone. Selain itu, ada juga developer kreatif yang mengembangkan game ini menjadi lebih bertema dan menarik untuk dimainkan secara digital.

Berdasarkan hasil penelitian dari Afrianti dkk (2018), menyimpulkan bahwa melalui permainan tradisional Ludo dapat meningkatkan kemampuan kognitif anak usia dini 5-6 tahun dalam aspek mengenal bentuk geometri, mengenal bilangan, dan mengelompokkan warna. Berdasarkan fakta di lapangan dan literatur maka penulis tertarik untuk membuat suatu kajian literatur tentang peran permainan ludo khususnya dalam mengembangkan kognitif anak. Dalam artikel ini penulis ingin 
membuktikan berdasarkan kajian literatur (pustaka) bahwa dengan bermain ludo dapat membantu pengembangan kemampuan kognitif anak.

\section{B. Pembahasan}

\section{Perkembangan Kognitif}

Perkembangan sebagai "Long-term changes in a person's growth feelings, patterns of thinking, social relationships, and motor skills". Sementara itu (Papalia, 2008) mengartikan perkembangan sebagai perubahan yang berkesinambungan dan progresif dalam organisme dari lahir sampai mati, pertumbuhan, perubahan dalam bentuk dan dalam integrasi dari bagian-bagian jasmaniah ke dalam bagianbagian fungsional, dan kedewasaan atau kemunculan pola-pola asasi dari tingkah laku yang tidak dipelajari.

Monks (2009) mengungkapkan bahwa Perkembangan dan pertumbuhan adalah dua hal mendasar pada seorang individu yang saling berkaitan satu sama lain dan tidak dapat berulang pada kembali seperti yang dikemukakan F.J. Monks, pengertian perkembangan menunjuk pada "suatu proses ke arah yang lebih sempurna dan tidak dapat diulang kembali". Perkembangan menunjuk pada perubahan yang bersifat tetap dan tidak dapat diputar kembali. Perkembangan juga dapat diartikan sebagai proses yang kekal dan tetap yang menuju ke arah suatu organisasi pada tingkat integrasi yang lebih tinggi, berdasarkan pertumbuhan, pematangan, dan belajar.

Dari beberapa pengertian diatas dapat disimpulkan bahwa perkembangan adalah perubahan individu dari segi pertumbuhan dan kematangan struktural yang progresif baik secara kualitatif maupun kuantitatif yang dimulai dari pra natal hingga dewasa yang hanya terjadi sekali dalam kehidupan seseorang.

Kemampuan kognitif merurut Yuliani (2006) adalah suatu proses berfikir, yaitu kemampuan individu untuk menghubungkan, menilai dan mempertimbangkan suatu kejadian atau peristiwa. Piaget (2010), anak-anak secara aktif membangun dunia kognitif mereka dengan menggunakan skema untuk menjelaskan hal-hal yang mereka alami. Skema adalah struktur kognitif yang digunakan oleh manusia untuk mengadaptasi diri terhadap lingkungan dan menata lingkungan ini secara intelektual. Piaget yang menyatakan bahwa dalam perkembangan kognitif untuk anak usia 5-6 tahun berada pada tahap pra operasional konkrit. Ciri/karakteristik utama perkembangan kognitif usia ini yakni anak mulai mempresentasikan benda-benda menggunakan pemikiran simbolis, belum mampu menggunakan pemikiran logis, dan menganggap setiap benda yang tak hidup memiliki perasaan

Menurut Piaget (2010), perkembangan kognitif mempunyai empat aspek, yaitu 1) kematangan, sebagai hasil perkembangan susunan syaraf; 2) pengalaman, yaitu hubungan timbal balik antara orgnisme dengan dunianya; 3) interaksi sosial, yaitu pengaruh-pengaruh yang diperoleh dalam hubungannya dengan lingkungan sosial, dan 4) ekuilibrasi, yaitu adanya kemampuan atau sistem mengatur dalam diri organisme agar dia selalu mempau mempertahankan keseimbangan dan penyesuaian diri terhadap lingkungannya. 
a. Kematangan

Kematangan sistem syaraf menjadi penting karena memungkinkan anak memperoleh manfaat secara maksimum dari pengalaman fisik. Kematangan membuka kemungkinan untuk perkembangan sedangkan kalau kurang hal itu akan membatasi secara luas prestasi secara kognitif. Perkembangan berlangsung dengan kecepatan yang berlainan tergantung pada sifat kontak dengan lingkungan dan kegiatan belajar sendiri.

b. Pengalaman

Interaksi antara individu dan dunia luar merupakan sumber pengetahuan baru, tetapi kontak dengan dunia fisik itu tidak cukup untuk mengembangkan pengetahuan kecuali jika intelegensi individu dapat memanfaatkan pengalaman tersebut.

c. Interaksi Sosial

Lingkungan sosial termasuk peran bahasa dan pendidikan, pengalaman fisik dapat memacu atau menghambat perkembangan struktur kognitif

d. Ekuilibrasi

Proses pengaturan diri dan pengoreksi diri (ekuilibrasi), mengatur interaksi spesifik dari individu dengan lingkungan maupun pengalaman fisik, pengalaman sosial dan perkembangan jasmani yang menyebabkan perkembangan kognitif berjalan secara terpadu dan tersusun baik.

Piaget membagi perkembangan kognitif anak ke dalam 4 periode utama yang berkorelasi dengan dan semakin canggih seiring pertambahan usia:

a. Periode sensorimotor (usia 0-2 tahun)

Bagi anak yang berada pada tahap ini, pengalaman diperoleh melalui fisik (gerakan anggota tubuh) dan sensori (koordinasi alat indra). Pada mulanya pengalaman itu bersatu dengan dirinya, ini berarti bahwa suatu objek itu ada bila ada pada penglihatannya. Perkembangan selanjutnya ia mulai berusaha untuk mencari objek yang asalnya terlihat kemudian menghiang dari pandangannya, asal perpindahanya terlihat. Akhir dari tahap ini ia mulai mencari objek yang hilang bila benda tersebut tidak terlihat perpindahannya. Objek mulai terpisah dari dirinya dan bersamaan dengan itu konsep objek dalam struktur kognitifnya pun mulai dikatakan matang. Ia mulai mampu untuk melambungkan objek fisik ke dalam symbol-simbol, misalnya mulai bisa berbicara meniru suara kendaraan, suara binatang, dll.

b. Periode praoperasional (usia 2-7 tahun)

Tahap ini adalah tahap persiapan untuk pengorganisasian operasi konkrit. Pada tahap ini pemikiran anak lebih banyak berdasarkan pada pengalaman konkrit daripada pemikiran logis, sehingga jika ia melihat objekojek yang kelihatannya berbeda, maka ia mengatakanya berbeda pula. Pada tahap ini anak masih berada pada tahap pra operasional belum memahami konsep kekekalan (conservation), yaitu kekekalan panjang, kekekalan materi, luas, dll. Selain dari itu, cirri-ciri anak pada tahap ini belum memahami dan belum dapat memikirkan dua aspek atau lebih secara bersamaan.

c. Periode operasional konkrit (usia 7-11 tahun) 
Pada umumnya anak-anak pada tahap ini telah memahami operasi logis dengan bantuan benda benda konkrit. Kemampuan ini terwujud dalam memahami konsep kekekalan, kemampuan untuk mengklasifikasikan dan serasi, mampu memandang suatu objek dari sudut pandang yang berbeda secara objektif. Anak pada tahap ini sudah cukup matang untuk menggunakan pemikiran logika, tetapi hanya objek fisik yang ada saat ini (karena itu disebut tahap operasional konkrit). Namun, tanpa objek fisik di hadapan mereka, anakanak pada tahap ini masih mengalami kesulitan besar dalam menyelesaikan tugas-tugas logika.

d. Periode operasional formal (usia 11 tahun sampai dewasa)

Anak pada tahap ini sudah mampu melakukan penalaran dengan menggunakan hal-hal yang abstrak dan menggunakan logika. Penggunaan benda-benda konkret tidak diperlukan lagi. Anak mampu bernalar tanpa harus berhadapan dengan dengan objek atau peristiwa berlangsung. Penalaran terjadi dalam struktur kognitifnya telah mampu hanya dengan menggunakan simbol-simbol, ide-ide, astraksi dan generalisasi. Ia telah memiliki kemampuan-kemampuan untuk melakukan operasi-operasi yang menyatakan hubungan di antara hubungan-hubungan, memahami konsep promosi.

Bermain memungkinkan anak-anak untuk "meregangkan " kognitif sendiri.

Dalam bermain anak selalu berperilaku melampaui rata-rata usianya, di atas perilaku sehari-hari, dalam bermain itu seolah-olah dia adalah kepala lebih tinggi dari dirinya sendiri " (Vygotsky, 1978, dalam Khadijah 2016), Selain itu, karena anak-anak bermain, perilaku mereka harus mengikuti standar atau harapan tertentu. Pada tahun-tahun awal sekolah dasar, anak-anak sering bertindak sesuai dengan bagaimana seorang ayah, guru, atau pelayan akan berperilaku. Dalam pertandingan grup terorganisir dan olahraga yang datang kemudian, anak-anak harus mengikuti set spesifik aturan. Dengan berpegang pada batasan tertentu pada perilaku mereka, anak-anak belajar untuk merencanakan ke depan, untuk berpikir sebelum bertindak, dan untuk terlibat dalam menahan diri-keterampilan yang penting untuk partisipasi sukses di dunia orang.

Menurut Bloom dalam Khadijah (2016), Ranah Kognitif memiliki tahapan sebagai berikut:
a. Mengingat
b. Memahami
c. Mengaplikasikan
d. Menganalisa
e. Mengevaluasi
f. Menciptakan (kreativitas)

Perkembangan kognitif menggambarkan bagaimana pikiran anak berkembang dan berfungsi sehingga dapat berpikir. Pikiran anak berkembang secara berangsur-angsur pada periode ini. Daya berpikir anak masih bersifat imajinatif dan egosentris pada masa sebelumnya, maka pada masa periode ini daya pikir anak sudah berkembang kearah yang lebih konkrit, rasional dan objektif. Daya ingat anak menjadi sangat kuat, sehingga anak benar-benar berada pada stadium belajar. 
Seseorang ketika belajar tentang suatu hal maka yang pertama kali adalah adanya stimulus berupa informasi dari luar kemudian informasi tersebut ditangkap oleh indera manusia yang merupakan suatu proses input, kemudian didalam otak informasi tersebut diintegrasikan dan disimpan serta dilakukan penelusuran apakah informasi tersebut pernah tersimpan atau tidak dalam memori jangka pendek maupun memori jangka panjang, setelah disimpan dalam memori dan setelah dilakukan penelusuran pada memori, informasi tersebut dapat direcall atau diingat kembali sebagai hasil output pada saat informasi itu dipanggil (Martin, 2002).

Copley mengungkapkan bahwa pembelajaran kognitif pada usia dini menitik beratkan kepada proses, pendidik sering mengatakan bahwa anak-anak akan belajar dengan melakukan, pernyataan ini bisa dikatakan benar namun bila kita teliti lebih dalam ternyata anakanak tidak hanya belajar dengan melakukan tetapi anak-anak akan belajar dengan melakukan, mengungkapkan, merefleksikan, mendiskusikan, melakukan pengamatan, investigasi, mendengarkan dan berpikir sebab akibat (Nurtaniawati, 2016: 5).

\section{Karakteristik Anak Usia 5-6 Tahun}

Pada saat anak berusia 5-6 tahun susunan koneksi syarafnya sudah berfungsi dengan baik sehingga dapat mengkoordinasikan otak dan gerak, baik secara fisik maupun non fisik dengan baik. Pada usia ini anak pada umumnya sudah memasuki sekolah TK atau sederajad. Karena itu, TK diciptakan sebagai jembatan untuk memudahkan periode transisi antara masa bayi dan masa kanakkanak. TK juga harus mulai memperkenalkan anak kepada budaya dan dunia yang lebih luas. Hal itu sebagai persiapan menghadapi pembelajaran akademik pada tahun-tahun selanjutnya. (Suratno, 2005).

Dalam pendidikan anak usia dini khususnya di Taman Kanak-kanak sesuai dengan Standar Tingkat Pencapaian Perkembangan Anak yang tertera dalam Peraturan Menteri Pendidikan dan Kebudayaan Republik Indonesia No 137 tahun 2014 lingkup perkembangan kognitif; (a) belajar dan pemecahan masalah, mencakup kemampuan memecahkan masalah sederhana dalam kehidupan seharihari dengan cara fleksibel dan diterima sosial serta menerapkan pengetahuan atau pengalaman dalam konteks yang baru; (b) berfikir logis, mencakup berbagai perbedaan, klasifikasi, pola, berinisiatif, berencana, dan mengenal sebab-akibat; dan (c) berfikir simbolik, mencakup kemampuan mengenal, menyebutkan, dan menggunakan konsep bilangan, mengenal huruf, serta mampu merepresentasikan berbagai benda dan imajinasinya dalam bentuk gambar.

Hurlock dalam Sujiono (2006) mengatakan bahwa "usia 3-5 tahun adalah masa permainan". Bermain dengan benda/alat permainan dimulai sejak usia satu tahun pertama dan akan mencapai puncaknya pada usia 5-6 tahun. Pada mulanya anak mengeksplorasi mainannya antara usia 2 dan 3 tahun, kemudian mereka membayangkan mainannya mempunyai sifat hidup (dapat bergerak, berbicara, dan merasakan), misalnya anak mengajak berbicara boneka kesayangannya. Bermain merupakan media yang amat diperlukan untuk proses berpikir karena menunjang perkembangan intelektual melalui pengalaman yang cara berpikir anak-anak.

Kegiatan pembelajaran yang dilakukan menurut buku pedoman pembelajaran di Taman Kanak-kanak (Depdiknas, 2007) antara lain:

a. Mengenal angka 1-10 secara bertahap, 
b. Menghitung benda 1 sampai 10,

c. Membandingkan besar- kecilnya nilai angka,

d. Operasi hitungan 1-5, menyebutkan angka secara berurutan 1-5 atau sebaliknya 5-1.

Perkembangan kognitif dalam kajian ini adalah perubahan pemahaman anak dalam mengenal konsep angka sederhana dengan dadu yang dimainkan anak dalam hal ini angka 1 sampai dengan 6 serta anak dapat mengetahui konsep banyak-sedikit dan panjang-pendek sebagai langkah awal anak dalam memahami matematika permulaan.

\section{Permainan Ludo}

Tanpa bermain dunia anak menjadi hampa. Perkembangan anak akan optimal jika distimulasi secara tepat. Sesuai dengan karakteristik anak bermain mempunyai banyak manfaat salah satunya mengembangkan kognitif/intelektual anak. Joan Freeman dan Utami munandar (dalam Andang Ismail, 2009) mendefinisikan permainan sebagai suatu aktifitas yang membantu anak mencapai perkembangan yang utuh, baik fisik, intelektual, sosial, moral, dan emosional. Desmita (2013) menjelaskan bahwa permainan mempunyai arti yang sangat penting bagi perkembangan kehidupan anak-anak. Permainan merupakan upaya di dalam mewujudkan joyfull learning atau pembelajaran menyenangkan untuk meningkatkan motivasi belajar pada siswa (Murwaningsih, 2016).

Raihan mengemukakan bahwa bermain ialah segala kegiatan yang dapat menimbulkan kesenangan bagi anak (Bermain dilakukan anak dengan suka rela, tanpa paksaan atau tekanan dari luar, dan adapun ciri-ciri aktivitas yang dipandang bermain itu: 1) Dilakukan dengan suka rela, anak melakukan kegiatan bermain tanpa ada unsur paksaan dari mana pun. 2) Dilakukan secara spontan. Anak akan spontan melakukan kegiatan bermain saat anak ingin melakukan 3) Berorientasi pada proses, bukan pada hasil. Yang terpenting bagi anak dalah bagaimana proses bermain, bukan bagaimana hasil permainan 4) Menghasilkan kepuasan, anak yang melaksanakan kegiatan bermain, dengan otomasi memiliki kepuasan tersendiri (Afrianti, dkk. 2018).

Menurut Catron dan Allen dalam Yuliani Nurani Sujiono (2009) mengemukakan bahwa pada dasarnya bermain memiliki tujuan utama yakni memelihara perkembangan dan pertumbuhan optimal pada anak usia dini melalui pendekatan bermain yang kreatif, interaktif dan terintegrasi dengan lingkungan bermain anak.

Menurut Rochjadi Hasan (Jose Jjoossee, 2012) bahwa dunia anak adalah dunia bermain, dimana bermain bagi mereka dapat dikatakan Core Actifity atau atau aktifitas utama. Slamet Suyanto (2005) menyatakan bermain memiliki peranan penting dalam perkembangan anak pada hampir semua bidang perkembangan, baik perkembangan fisik-motorik, bahasa, intelektual, moral, sosial, maupun emosional.

Montolalu, dkk (2005) mengungkapkan bahwa "manfaat bermain antara lain:

a. Bermain memicu kreativitas

b. Bermain bermanfaat mencerdaskan otak

c. Bermain bermanfaat menanggulangi konflik

d. Bermain bermanfaat melatih empati

e. Bermain bermanfaat melatih pancaindera 
f. Bermain sebagai media terapi (pengobatan)

g. Bermain itu melakukan penemuan.

Berikut ini adalah pengertian tentang permainan ludo menurut beberapa referensi: Kata Ludo berasal dari bahasa latin yang berarti game (permainan). Permainan ludo sangat menarik jika dimainkan beramai-ramai. Papan permaian ini terdiri dari empat warna yang mewakili setiap pemain. Umumnya, permainan ini dilakukan oleh 2 sampai 4 orang pemain. Permainan ini merupakan simplifikasi dari permainan orang India, Pachisi. Pachisi diperkirakan sudah dimainkan sejak 500 tahun yang lalu sebelum masehi. Meskipun mendapat pengaruh India, permainan ludo yang muncul pada 1896 ini mulai dipatenkan di Inggris ( Hapsari, 2015: 19).

Ludo adalah permainan papan bahasa Jerman dalam bentuk game Cross and Circle, mirip dengan game India Pachisi, permainan Amerika Parcheesi, dan permainan bahasa Inggris Ludo. permainan tradisional asal India ini menggunakan papan seperti 'Ular Tangga' atau 'Monopoli' dan bisa dimainkan oleh dua hingga empat orang. Setiap pemain akan berlomba untuk menjadi yang tercepat dalam mengirimkan 4 token yang dimiliki dari 'markas' ke bagian tengah papan yang jadi tujuan terakhir game (Maehadi, 2019: 2)

Permainan ludo adalah permainan tradisional dimana dalam permainan yang dimainkan 2-4 orang yang diharuskan untuk mengatur strategi memindahkan 4 bidak pion dengan menggunakan dadu (Ningsih dan Pritandhari, 2019: 52). sedangkan menurut Kristiani (2015:101) Ludo adalah permainan yang dimainkan oleh dua sampai empat orang, dimana masing-masing pemain menggunakan bidak dengan warna yang berbeda dengan tujuan mencapai finish. Permainan ludo adalah jenis permainan yang menyenangkan dan menghibur untuk dilakukan, permainan ini dapat dengan mudah dibuat dan diperbanyak. Kemudian Menurut Mulyani (2013:124), Ludo adalah permainan yang terdiri dari selembar kertas bergambar kotak-kotak sebanyak 4 buah kotak besar dan 72 kotak kecil.

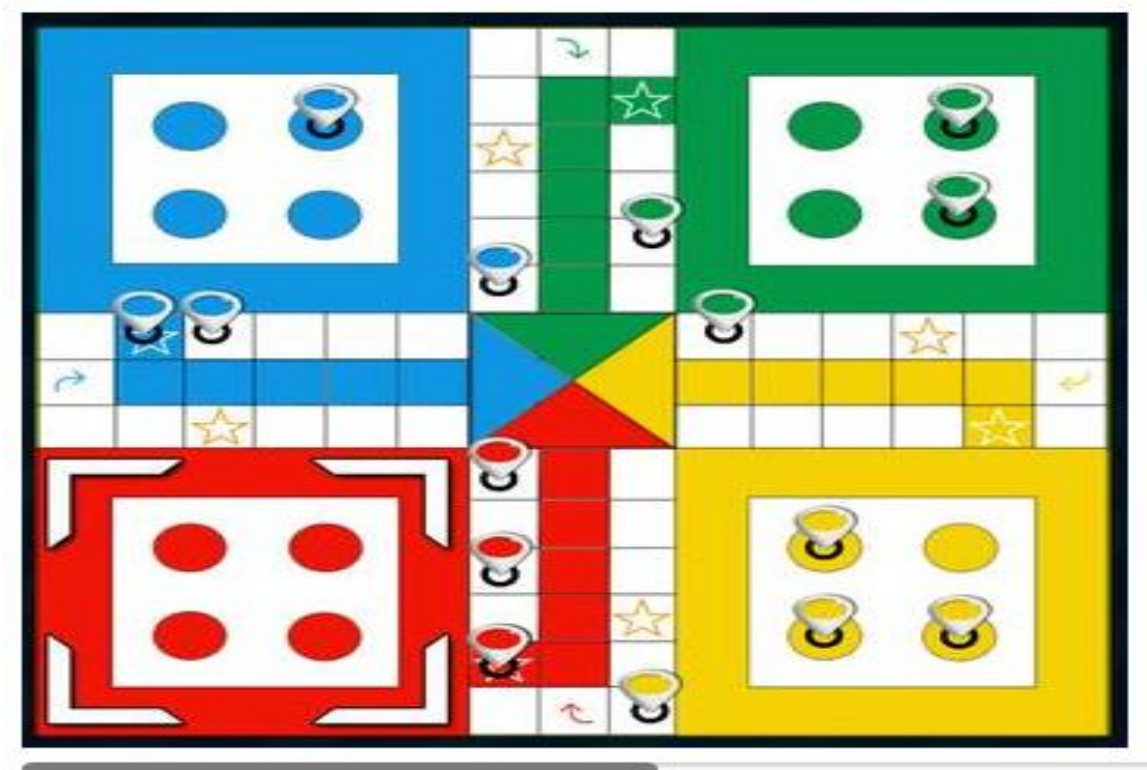

Gambar 1. Papan Ludo

Sumber: https://apkpure.com/id/ludo-game-download-ludo-star/free. 
Cara bermain ludo adalah Aturan main dalam permainan Ludo ini harus terdiri dari 2-4 orang yang harus mengatur strategi untuk berlomba memindahkan empat pion dengan menggunakan dadu. Pemenangnya merupakan pemain yang semua bidaknya paling cepat dipindahkan ke tujuan. Pemain juga memiliki opsi untuk memainkan game melawan komputer, melawan teman, atau bahkan melawan pemain dari seluruh dunia. Saat memulai permainan, empat pion ludo disusun pada "rumah" yang sesuai dengan warna yang terdapat di sudut papan. Untuk mengeluarkan pion ludo dari rumah tersebut, setiap pemain harus mendapatkan hasil kocokan dadu dengan angka yang sama, yaitu angka '6'. Pemenang ditentukan dengan melihat siapa yang paling pertama meletakkan seluruh pion ludo ke titik akhir.

Aspek-Aspek Perkembangan pada Anak dalam Permainan Ludo yaitu: 1) Melatih kemampuan motorik halus, 2) Melatih Kesabaran dan ketelitian (emosional), 3) Melatih jiwa sportifitas, 4) Melatih kemampuan menganalisa (kognitf), dan 5) Menjalani kontak sosialisasi. Sedangkan manfaat permainan tradisional ludo adalah 1) Dapat melatih otak kiri anak untuk berpikir, 2) Melatih strategi mengumpulkan angka terbanyak agar bisa mengalahkan lawan, sepertinya sederhana, namun ketika dimainkan, otak kiri dan kanan aktif dengan perhitungan numerik, 3) Untuk perkembangan dan pembentukan otak kanan, 4) Melatih anak dalam bekerjasama, dan 5) Melatih emosi anak warna (Afrianti,dkk 2018: 54).

Berdasarkan kajian literatur dapat dihipotesiskan bahwa permainan ludo dapat membantu anak dalam terutama dalam aspek kognitif khususnya dalam bidang matematika permulaan. Dengan bermain ludo, anak dapat mengenal konsep angka sederhana dengan dadu yang dimainkan anak dalam hal ini angka 1 sampai dengan 6 serta anak dapat mengetahui konsep banyak-sedikit dan panjang-pendek.

\section{Simpulan}

Berdasarkan kajian literatur dapat disimpulkan bahwa permainan ludo dapat membantu anak perkembangan kognitif anak khususnya anak dapat mengenal konsep angka sederhana dengan dadu yang dimainkan anak dalam hal ini angka 1 sampai dengan 6 serta anak dapat mengetahui konsep banyak-sedikit dan panjang-pendek, sebagai langkah awal dalam pengembangan kemampuan matematika awal. Sebagai saran dalam kajian ini yakni guru perlu memodifikasi permainan ludo dari bahanbahan yang disekitar anak. Sehingga dapat dimainkan oleh anak-anak di daerah pedesaan.

\section{DAFTAR PUSTAKA}

Afrianti Sulis, Musnar Indra Daulay Dan Putri Asilestari, 2018. Meningkatkan Kemampuan Kognitif Anak Dengan Permainan Ludo, Journal On Early Childhood, Vol 1 No 1.

Andang Ismail. 2006. Educations Games: Menjadi Cerdas Dan Ceria Dengan Permainan Edukatif. Yogyakarta: Pilar Media-Anggota IKPJ.

Desmita, 2013. Psikologi Perkembangan, Bandung: PT. Remaja Rosdakarya.

Depdiknas. 2007. Pedoman Pembelajaran Berhitung Permulaan di TK. Jakarta: Depdiknas 
Hapsari Merlyana Dwi, 2015. Efektivitas Ludo Word Game (LWG) Dalam Meningkatkan Penguasaan Kosakata Bahasa Jepang Di Smk Mitra Karya Mandiri KetanggunganBrebes, Skripsi Universitas Negeri Semarang.

Khadijah, 2016, Pengembangan Kognitif Anak Usia Dini, Perdana Publishing Medan

Kristiani, Dian. 2015. Ensiklopedia Negeriku (Permainan Tradisional). Jakarta: Bhuana Ilmu Populer.

Jawati Ramaikis, 2013 Peningkatan Kemampuan Kognitif Anak Melalui Permainan Ludo Geometri Di PAUD Habibul Ummi II, Jurnal Spektrum PLS Vol. I, no.1, April 2013

Jose Jjoossee. 2012. Bermain Sambil Belajar. diakses pada tanggal 18 Februari 2020 (http://bermainsambilbelaja.blogspot.com/).

Montolalu, dkk. 2005. Bermain dan Permainan Anak. Jakarta : Universitas Terbuka

Murwaningsih, Esti Anugraheni, Susantini, Endang Dan Wahono Widodo. 2016. Pengembangan Permainan Kotak-Katik Ipa Pada Materi Sistem Ekskresi Sebagai Media Pembelajaran Siswa di SMP, (online), vol.4 nomor 03, (http:// jurnalmahasiswa. unesa.ac.id/ index.php/ pensa/ article/view/16739/20717, diunduh 28 pebruari 2020).

Martin, g. (2002). Tolong! Anak saya sulit belajar. Jakarta: Harvest Publication House.

Mulyani, Novi. 2013. Super Asyik Permainan Tradisional Anak Indonesia. Yogyakarta: Diva Press.

Marhadi, 2019. Permainan Ludo Sebagai Media Pembelajaran Pendidikan Jasmani, Olahraga Dan Kesehatan Pada Siswa Sekolah Dasar. Tadulako Journal Port Sciences And Physical Education Volume 7, Nomor 2 Juli - Desember 2019 ISSN 2581-0383

Monks, F.J. A.M.P. Knoers, Siti Rahayu Haditono, 2009, Psikologi Perkembangan: Pengantar Dalam Berbagai Bagiannya, Gajah Mada University Press, Yogyakarta.

Ningsih Sri Armiyanti Dan Meyta Pritandhari, 2019. Jurnal Promosi Jurnal Pendidikan Ekonomi UM Metro vol.7. no.1. 2019

Nurtaniawati, 2016. Peran Guru Dan Media Pembelajaran Dalam Menstimulasi Perkembangan Kognitif Anak Di Taman Kanak-Kanak, Universitas Pendidikan Indonesia, repository.upi.edu perpustakaan.upi.edu

Piaget, Jean, \& Barbel Inhelder, 2010. Psikologi Anak, Terj. Miftahul Jannah, Pustaka Pelajar, Yogyakarta, Cet. 1, 2010.

Papalia, D.E, Olds, S.W., \& Feldman, R.D. (2008). Human Development (9th ed). New York:McGraw Hill

Slamet Suyanto. 2005. Dasar-Dasar Pendidikan Anak Usia Dini. Yogyakarta: Hikayat Publishing.

Sujiono, Yuliani Nurani. 2009. Konsep Dasar Pendidikan Anak Usia Dini. Jakarta: PT Indeks.

Suyanto, 2005. Konsep Dasar Anak Usia Dini : Jakarta : Departemen Pendidikan Nasional.

Suyanto Slamet. 2005. Konsep Dasar Pendidikan Anak Usia Dini. Depdiknas, Dirjen PT, Direktorat Pembinaan Pendidikan Tenaga Kependidikan Dan Ketenagaan PT. Jakarta.

Suratno, 2005. Pengembangan Kreativitas Anak Usia Dini, Jakarta: Departemen Pendidikan Nasional Direktoral Jenderal Pendidikan Tinggi, Direktorat Pembinaan Pendidikan Tenaga Kependidikan Dan Ketenagaan Perguruan Tinggi.

Sujiono Yuliani Nurani, dkk. 2006. Metode Pengembangan Kognitif. Jakarta: Universitas Terbuka.

Zeed Mestika, 2014. Metode Penelitian Kepustakan, Jakatra: Yayasan Pustaka Obor. 